\title{
Furtwängler Garden: \\ the sacrum as reference field
}

\section{Furtwängler Garden:}

sacrum jako pole referencyjne

\begin{abstract}
The sacred as initial layer in landscape architecture

Salzburg's entire historic centre is a World Heritage Site. In this context, the Furtwängler Garden project, which was completed in 2010 , is defined by religious architecture and influenced by the spirituality of the site. This paper addresses the questions: Which sources of sacral traditions play a role? What are the consequences of such an approach? Which kind of transformations in landscape architecture evolve? How does "the sacral" become manifest in contemporary landscapes that are not religiously connoted spaces?
\end{abstract}

Keywords: sacrum, garden, traditions

\section{Streszczenie}

Całe historyczne centrum Salzburga wpisane jest na Listę Światowego Dziedzictwa UNESCO. W tym kontekście projekt Furtwängler Garden, który został ukończony w 2010 r., jest określany przez architekturę religijną i pod wpływem duchowości tego miejsca. W niniejszym artykule poruszono pytania: jakie źródła tradycji sakralnych odgrywają rolę? Jakie są konsekwencje takiego podejścia? Jakie przekształcenia w architekturze krajobrazu ewoluują? W jaki sposób sakralność manifestuje się we współczesnych krajobrazach, które nie są religijnie konotowanymi przestrzeniami?

Słowa kluczowe: sacrum, ogród, tradycje 


\section{NEW DESIGN IN WORLD HERITAGE SETTING}

As set forth by ICOMOS, Salzburg's entire historic centre is a World Heritage Site. This fabric is to a great extent characterized by religious architecture. Towards the north and west, the Furtwängler Garden is surrounded by the building of the old University, still serving as a theology faculty; towards the southern border are the former stables of the archbishop (1607), adapted by Clemens Holzmeister as the Salzburg Festival Hall. On the east side of the site is the Colleges Church (1707) by J. B. Fischer von Erlach: a sacred mountain, so to speak.

\section{HISTORIC TYPOLOGY}

The historic fabric of Salzburg, situated on the left bank of the river Salzach, dates back mainly to the medieval and Renaissance periods, and is not endowed with public parks. Mirabell Garden (1730), is located on the right side of the river. It is presently a public park. The Gardens of Hellbrunn - a Renaissance jewel in Central Europe and the first mannerist garden north of the Alps - were built in the early seventeenth century on the edge of Salzburg.

Characteristic, however, of mediaeval and Renaissance Salzburg are monastery gardens and cemeteries. They are closed, or in some cases, semi-closed areas, framed by walls. They are invisible from outside and, to this day, give rise to a specific ritual: they are quiet places, sites where our behaviour and movement diverges from the norm, where the number of functions is limited. These gardens are not expected to be part of a spectacle, to suggest an "event" - the exact opposite of contemporary public gardens.

\section{TRANSFORMING TRADITION}

The basic question for us as landscape architects has been: What approach can we - should we - take to this cultural background? The functional requirements set forth - in the form of requests and suggestions - by the municipality, by the citizens, and by different powerful players (for example, the Salzburg Festival, the University, and the Tourism Association) were endless, and the pressure to arrive at a flexible and multifunctional result (spells of the present planning alchemy) was enormous: as a play-ground, event-ground, leisure-ground, etc. We decided to refer to the tradition of this particular urban fabric, not by copying certain formal solutions, but by transforming and developing them into a contemporary design that reflects the inflationary diversity of these expressed needs and functions. 


\section{FRAME AND CORE}

The enclosure in the historic typology (of the monastery and cemetery gardens) seemed to us a promising reference element. Tilting the enclosure, so-to-speak, from the vertical into the horizontal, we created a 5-metre-wide paved surface serving as an unusually generous area for walking and lingering at the same time. A frame with again frame-like connections. The lawn areas within this net of frames sit $28 \mathrm{~cm}$ deeper - a sunken centre of sorts, a quiet midst. One can enter along the steps or along a short ramp. This sunken green core appears to the visitors as a distinct space within the garden.

\section{DESIGN INTENTIONS}

The intention was to signal a slowdown, to induce a calm spirit into the busy atmosphere of tourists, festival visitors, students and other locals. Design strategies are of course often not so explicit, but rather implicit or intuitive. In this project we sought a "contro corrente" solution - in contrast to the Zeitgeist's design of green open spaces, in contrast to the current, short-term trends - or, in other words, a viable reference residing in the genius loci. A risky approach, based on a quite minimalistic intervention, yet with high atmospheric quality. Materials, details, the play between aspects of the familiar and the unfamiliar had to be used in a very precise way.

Elements of Sacrum as described above meet a second design layer referring to a likewise strong local tradition: That of Scenographic Representation, recognizable in the neighbouring eighteenth-century church; today symbolized by the Salzburg Festival, founded by Max Reinhardt, a man of almost Baroque-inspiration. The quiet midst of the Furtwängler Garden is flanked on two sides by $140 \mathrm{~cm}$ high hedges. This kind of stage setting creates protected niches in the Garden, subspaces without losing the perception of the whole site.

\section{ATMOSPHERIC DETAILS}

The sacrum in the design of this public place also appears indirectly in some details:

- The single chairs and double chairs we selected induce a kind of "concentrated stay." The decision to use this type of furniture expresses a specific approach of ours: "form follows atmosphere." The chairs are reminiscent of existing park benches but are distinctly different: We stay close to each other: alone, but not lonely.

- The ramps leading to the sunken lawn might seem superfluous, but they call attention to the significance of situating the ground level just $28 \mathrm{~cm}$ lower than the surroundings. 
- The unusual overlapping of the hornbeam hedges and the hydrangea is a poetic statement, creating astonishment through the use of familiar plants: a silent surprise.

\section{REFLECTION}

Various slow-paced spaces unfold in the Furtwängler Garden: largo/adagio con brio/ andante lento. The new site reclaims certain structural features still present in the mediaeval and Renaissance fabric of Salzburg and transforms them into the wilderness of public space of the twenty-first century.

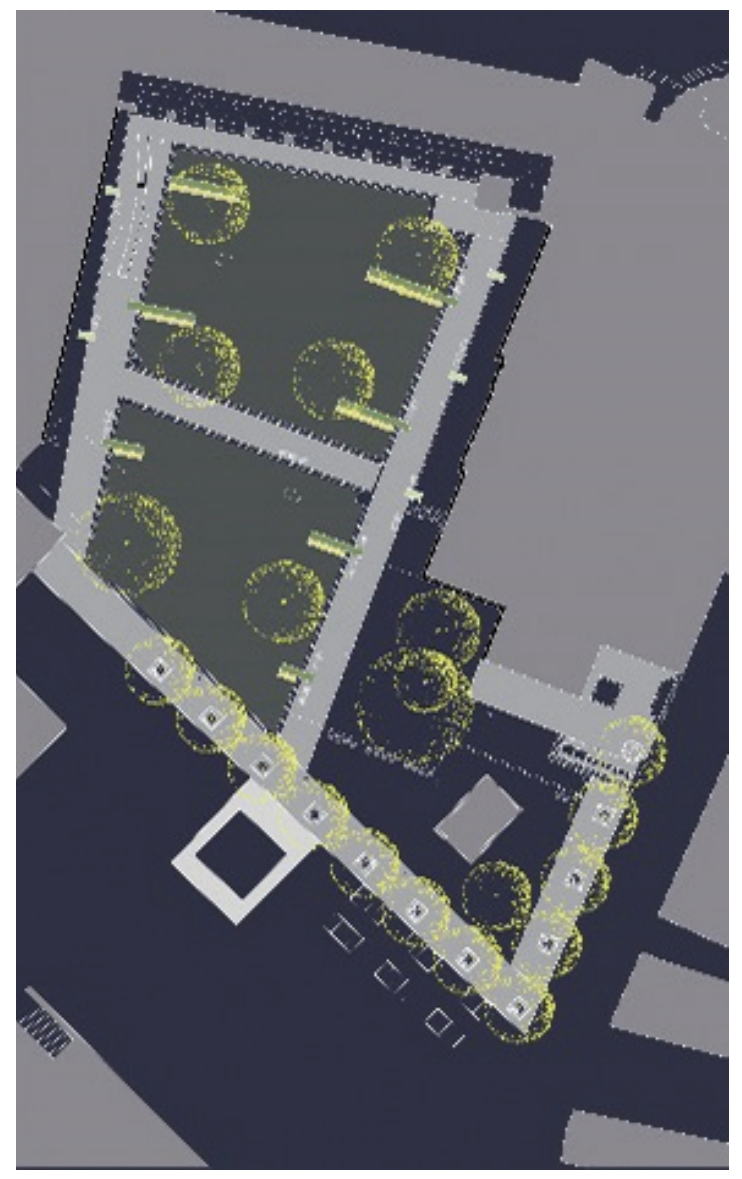

II. 1. Layout plan

(source: Auböck+Kárász) 
II. 2. View toward Hohensalzburg Castle (source: Auböck+Kárász)
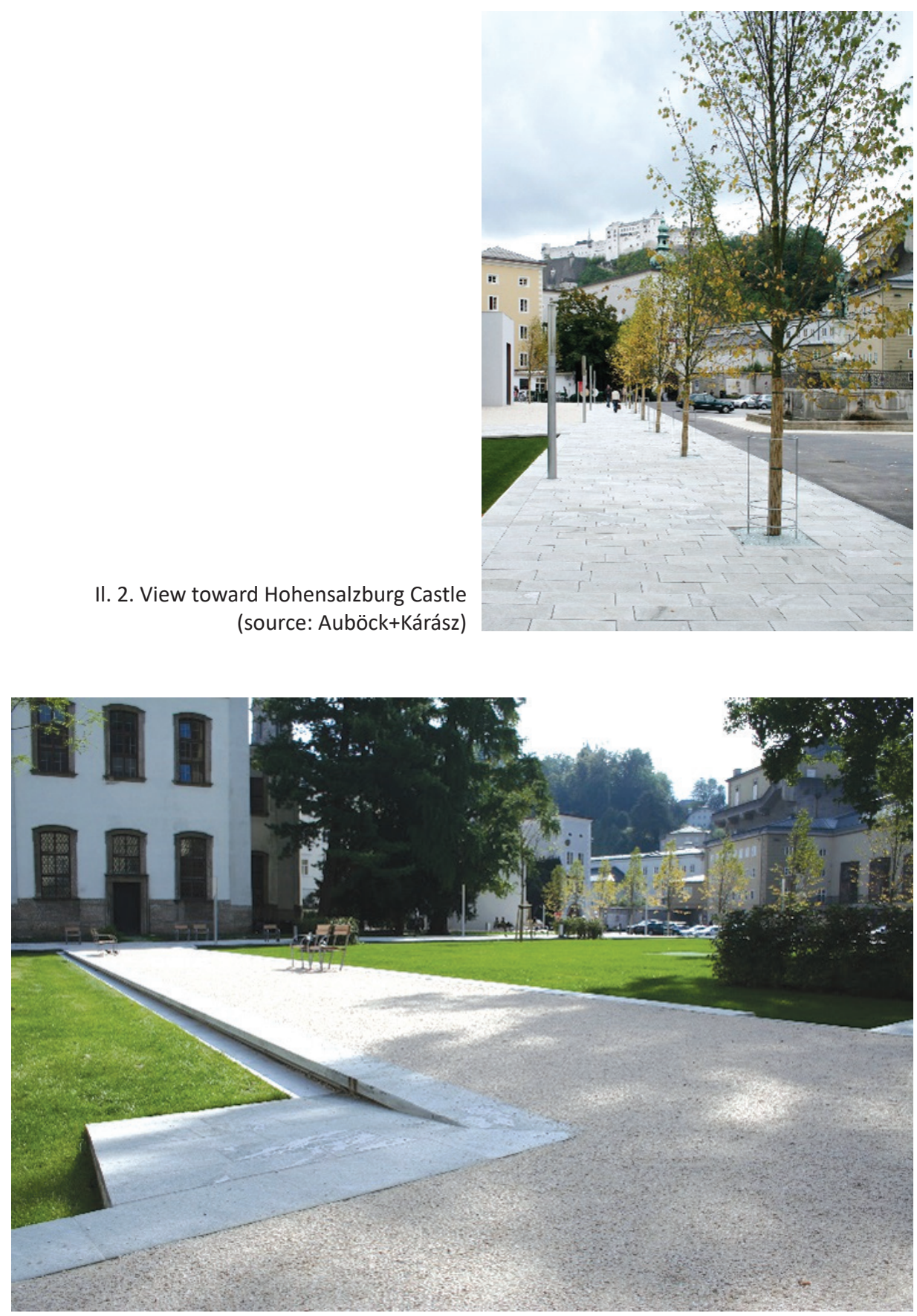

II. 3. View of the garden area (source: Auböck+Kárász) 


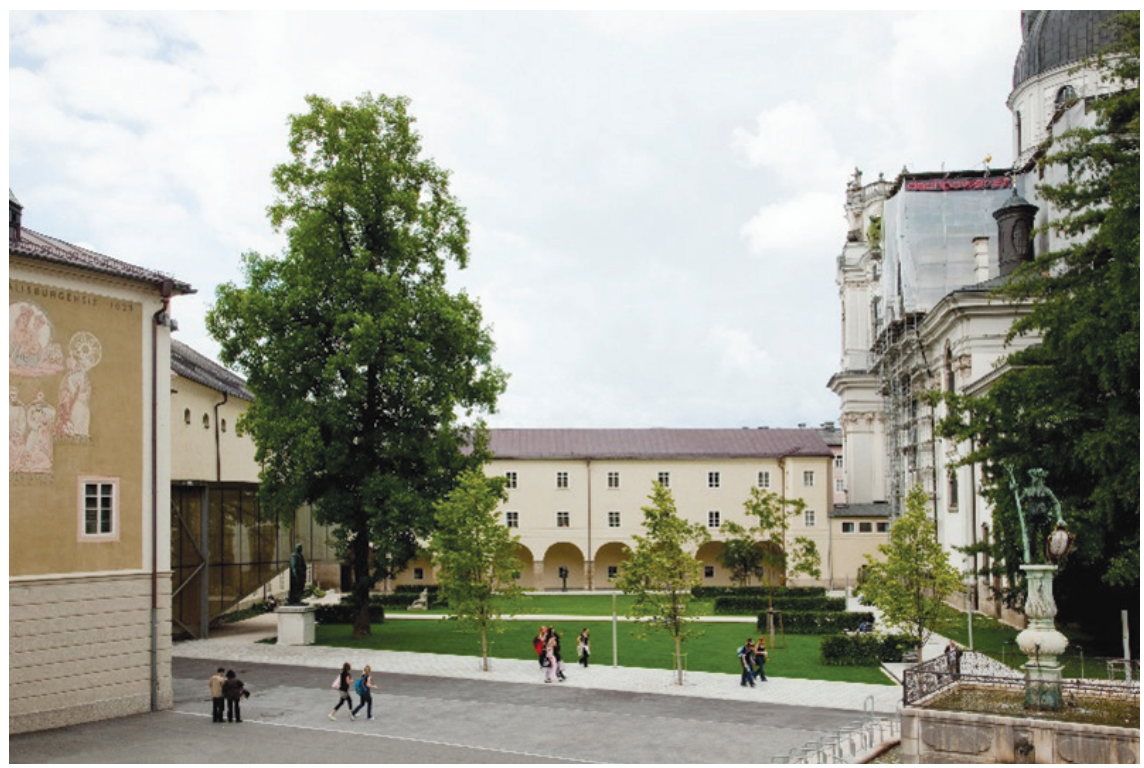

II. 4. Details of steps and lawn border (photo by: Andrew Phelps)

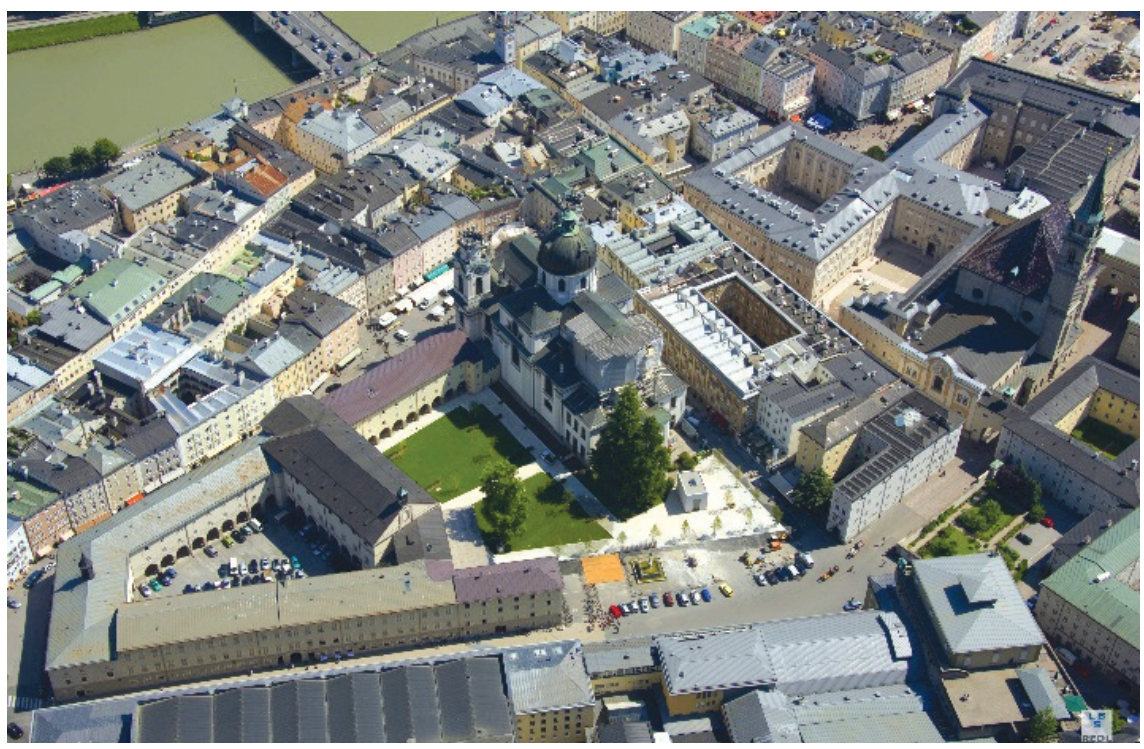

II. 5. Aerial view (source: Municipality of Salzburg)

ADRES BIBLIOGRAFICZNY ARTYKUŁU: Kárász J., Furtwängler Garden: the sacrum as reference field, Przestrzeń/Urbanistyka/ Architektura, 1/2018, s. 163-168.

DATA AKCEPTACJI OSTATECZNEJ WERSII DO OPUBLIKOWANIA: 25.06.2018. 